\title{
Галина Манюк,
}

Львівське регіональне відділення

Національної школи суддів України

ORCID: https://orcid.org/0000-0003-1384-9479

\section{АДМІНІСТРАТИВНО-ПРАВОВІ ПРОБЛЕМИ ФІНАНСУВАННЯ УНІВЕРСИТЕТІВ}

Досліджено закономірності становлення і розвитку системи фінансового забезпечення функціонування університетів як иеетрального елемента системи закладів вищої освіти університетського рівня. Фінансування університетів розглядається, як елемент забезпечення їх функиіонування і в розрізі двох його форм: публічного та приватного. Проаналізовано зарубіжний та украӥнський досвід правового регулювання фінансування університетів, зокрема започатковані в 2020 р. новели фінансування вітчизняних закладів вищої освіти університетського рівня.

Ключові слова: університет, освіта, вищча освіта, заклад вищої освіти, фінансування.

Бібл.: 10.

Манюк $\Gamma$.

Административно-правовые проблемы финансирования университетов

Исследовано закономерности становления и развития системы финансового обеспечения функционирования университетов как иентрального элемента системы высших учебных заведений университетского уровня. Финансирование университетов рассматривается как элемент обеспечения их функичионрования и в разрезе двух его форм: публичного и частного. Проанализирован зарубежный и украинский опыт правового регулирования финансирования университетов, в частности начатые в 2020 году новелль финансирования отечественных высиих учебных заведений университетского уровня.

\section{Manyuk G.}

Administrative problems of university financing

The article is devoted to the study of patterns of formation and development of the system of financial support for the functioning of universities as a central element of the system of higher education institutions at the university level and to determine on this basis the relevant tendencies and problems.

It is noted that the issue of retaining universities, providing their financial and logistical needs has been urgent since their emergence as a public institute, and it remains so today. In particular, the relevant issues are characterized in Ukraine. The principles of public financing of domestic universities have recently undergone significant changes, which have already started to be implemented since 2020.

In the world, public funding for higher education institutions is through the prism of implementing appropriate public policy. Public funding for higher education is provided through national and local budgets. World practice has a diversity of funding models for universities. Based on the analysis, they can be broadly divided into two types, depending on the source of funding: public (state and municipal) and private. The financial models used in the practice of European universities take into account the effectiveness of the university's activities, but they differ depending on the type of activity of the university, for example, some financial models are used for training and others for research activities.

Regarding Ukraine, there is reason to note the general trends in the development of the countries with economies in transition, in view of the fact that the government (the state) remains the main source of funding for higher education, while the decrease of the state budget for financing the education of students is evident. training, development of new programs and investment in research.

A dramatic change in the mechanism of public funding of Ukrainian universities began in late 2019, when the Ministry of Education and Science of Ukraine significantly changed the approach to financing higher education. These changes are envisaged in the Concept of Reforming Financing and Management of Higher Education Institutions.

In general, it should be noted that the search for and development of an effective university funding model should take into account all the activities of the university and be based on efficiency, transparency and autonomy. This should, in turn, increase the accountability of all participants in the educational process and enable the use of limited financial resources.

Keywords: university, education, higher education, institution of higher education, financing. 
МанюкГ.

Адміністративно-правові проблеми фінансування університетів

Постановка проблеми. Проблемами фінансування університетів зацікавлені як зарубіжні, так і вітчизняні вчені та безпосередньо для вищий керівний склад ВНЗ протягом тривалого часу, а відтак ці питання є предметом жвавої дискусії. Сьогодні заклади вищої освіти університетського рівня стикаються 3 такими проблемами, як обмеження бюджетних фінансових ресурсів, зниження власних надходжень, демографічна криза, старіння населення тощо. Зазначені обставини посилюють жорстку конкуренцію між вищими навчальними закладами щодо їх публічного фінансування, яке необхідне для забезпечення успішної діяльності університетів. Для того, щоб «вижити» в цій конкурентній боротьбі, університети вдаються до різноманітних моделей фінансування своєї діяльності. Успішне вирішення поставлених завдань пов'язане з багатьма чинниками. Однак насамперед важливо враховувати наявний світовий і вітчизняний досвід фінансування університетів як закладів вищої освіти.

Аналіз останніх досліджень і публікацій. Проблематика фінансування вищої школи доволі активно досліджується у вітчизняній науці. Особливої уваги заслуговують праці, що розкривають адміністративноправові засади фінансування закладів вищої освіти, передовсім на дисертаційному та монографічному рівнях. Вагому роль у дослідженні вказаних питань становлять наукові пошуки таких учених, як: Д. Л. Ворон, Т. О. Губанова, Н. Л. Губерська, А. М. Детюк, С. М. Кушнір, М. І. Легенький, В. М. Савіщенко та ін. Проте видається, що недостатньо ще розкриті адміністративно-правові аспекти фінансування закладів вищої освіти (далі - ЗВО) університетського рівня (за європейською класифікацією).

Метою дослідження $\epsilon$ вивчення закономірностей становлення і розвитку системи фінансового забезпечення функціонування університетів як центрального елемента системи закладів вищої освіти університетського рівня та визначення на цій основі відповідних тенденцій та проблем.

Виклад основного матеріалу дослідження. Питання утримання університетів, забезпечення ï фінансових та матеріально-технічних потреб було актуальним 3 часу їх виникнення як суспільного інституту, і таким воно все ще є сьогодні. Особливою гостротою відповідні питання характеризуються в Україні. Засади публічного фінансування вітчизняних університетів останнім часом зазнають суттєвих змін, які вже почали реалізовуватися з 2020 р. Перед тим, як їх проаналізувати, зупинимося на оцінювпнні досвіду інших країн у відповідній сфері.

У світі публічне фінансування закладів вищої освіти здійснюється крізь призму реалізації відповідної державної політики. Публічне фінансування вищої школи реалізується через загальнодержавні та місцеві бюджети. Традиційно проблемою урядів країн є пошук балансу між дохідною та видатковою частинами державного бюджету, що безпосередньо визначає можливості держави щодо підтримки університетів. Уряди всього світу шукають можливості забезпечити політично і соціально обгрунтовані потреби в умовах усе більш дефіцитних податкових надходжень. Конкуренцію фінансуванню вищої освіти становлять соціальні виплати, витрати на охорону здоров'я, загальну освіту, інфраструктуру, безпеку та інші соціальні цілі. Виборці багатьох країн стають все більш консервативними, особливо у неприязні до оподаткування та витрат уряду, які вони вважають марнотратством. Відтак багато європейських країн, 3 їх дорогим соціальним забезпеченням, на яке витрачається від третини до більш ніж половини ВВП, намагаються перекласти частину своєї відповідальності на приватний сектор і скоротити бюджетний дефіцит відповідно до вимог Європейської спільноти.

Щодо України, то є підстави констатувати слідування загальним тенденціям розвитку країн 3 перехідною економікою в частині того, що уряд (держава), як і раніше, є основним джерелом фінансування для вищої освіти, водночас очевидне зменшення можливостей державного бюджету для фінансування навчання студентів, підвищення якості навчання, освоєння нових програм та інвестицій у наукові дослідження [1].

3 огляду на глобальне скорочення державних фінансових ресурсів значної популярності набуває модель фінансування університетів за результатами діяльності (performance-based funding, РВF). Ця модель має ряд підвидів, найпопулярнішими з яких є фінансування на основі підписання контрактів між BВ3 та урядом щодо здійснення чітко вказаних видів діяльності чи виконання послуг, за які університет отримує державні кошти.

Також не менш популярним є фінансування ВНЗ на основі формули, відповідно до якої інституція отримує бюджетні кошти саме за досягнення певних заздалегідь визначених показників. Ці показники включені до формули, за допомогою якої визначається обсяг фінансування. Вперше запровадження такої моделі відбулося в американському штаті Теннессі у 1978 р. Згодом модель фінансування університетів за результатами діяльності поступово почали застосовувати в інших штатах. Сьогодні їі використовує абсолютна більшість штатів. Здебільшого за допомогою цієї моделі в США надається лише частина фінансування - від 5\% до 50\% [1]. 
Країни Європейського Союзу почали запроваджувати модель фінансування університетів за результатами їхньої діяльності і для фінансування певної частини витрат університетів 3 середини 1990-х років. Сьогодні розрахунок обсягу публічного фінансування за допомогою формули, що містить певні індикатори, здійснюється практично у всіх європейських країнах.

Дослідники поділяють показники, які включені до формули, на дві основні групи: індикатори витратності (input) та індикатори результату (output). До першої групи здебільшого належить кількість студентів різних рівнів та програм, кількість викладачів або ж їх співвідношення. Друга група має ширший діапазон показників: кількість випускників, обсяг позабюджетних надходжень, кількість дослідницьких контрактів, показники цитувань, патентів, працевлаштування випускників, досягнення стратегічних цілей [2, c. 24].

Застосування тих чи інших показників залежить від цілей, які ставлять в процесі впровадження моделі фінансування університетів за результатами діяльності, та вихідних умов, у яких перебуває вищий навчальний заклад або вид їхньої діяльності (викладання, дослідження). Тобто універсальних показників, які дають однаковий ефект у різних системах, немає.

Більшість освітніх систем використовують модель фінансування за результатами діяльності для покриття видатків на навчання студентів, водночас основним критерієм $€$ кількість випускників. Також цю модель часто застосовують в процесі фінансування наукових досліджень, де береться до уваги кількість публікацій та фінансування наукових досліджень із зовнішніх джерел. Різновидом моделі фінансування університетів за результатами діяльності є підписання контрактів, в яких узгоджуються визначені завдання між університетами та урядом або замовником послуг [2, с. 25].

Фінансування вищої освіти у світі все частіше здійснюється на основі змішаних джерел, водночас простежується тенденція до зростання важливості приватного фінансування навчання. Механізми розподілу витрат на навчання доволі часто переглядаються, а для визначення фактичних витрат на університет, на програму чи курс все частіше враховуються різноманітні показники ефективності.

Фінансування науково-дослідної діяльності університетів в на сьогодні все більше відрізняється від фінансування викладацької діяльності і враховує свої показники ефективності. Багато урядів використовують конкурентні елементи в процесі виділення державних коштів для ВНЗ. Йдеться про здійснення заходів з підвищення ефективності за рахунок «формули фінансування» або про розподіл ресурсів на основі оцінювання проєктних пропозицій. Відповідні форми для розподілу ресурсів за результатами діяльності можна знайти в більшості ВНЗ.

Таким чином, у практиці європейських університетів застосовується велика різноманітність фінансових моделей, які враховують ефективність діяльності ВНЗ, але вони відрізняються залежно від виду його діяльності, наприклад одні фінансові моделі використовуються для навчання і зовсім інші - для науково-дослідної активності.

Коротко розглянемо найбільш популярні моделі фінансування, які активно використовуються у більшості європейських університетів, водночас зазначимо, що в одному університеті може успішно поєднуватися кілька фінансових моделей.

Провідні позиції серед фінансових механізмів розподілу державних коштів у більшості європейських університетів сьогодні займає грантове фінансування. За допомогою грантів фінансуються витрати на навчання, поточні операційні витрати та наукові дослідження. Університети є відповідальними за розподіл та перерозподіл такого фінансування в середині самого університету відповідно до своїх потреб. Вся сума грантового фінансування може бути визначена у різний спосіб: через попередні домовленості, на основі попередніх показників, через формулу фінансування чи виконання контрактів. Доволі часто ці елементи поєднуються, відтак частина грантового фінансування виділяється на основі домовленостей, а інша частина отримується на основі укладених контрактів чи розраховується за формулою [3].

Крім того, все частіше простежується розподіл державних коштів на основі конкурентних змагань між університетами, що пов'язані з певними проєктами. Згідно з цим підходом кошти розподіляються між установами на конкурсній основі щодо представлених пропозицій у процесі конкурсного відбору. Ці кошти, як правило, виділяються на визначений проєкт або направлені на досягнення конкретних цілей чи пріоритетів, визначених спонсором.

В окремих випадках зустрічається спільне фінансування, його суть полягає в тому, що головний фундатор згоден на фінансування узгодженого виду діяльності університету чи проєкту, за умови, що університет також братиме участь у фінансуванні цього ж проєкту у попередньо визначених розмірах за рахунок власних коштів [4]. 
МанюкГ.

Адміністративно-правові проблеми фінансування університетів

Не так часто, але все ж таки наявне в окремих країнах благодійне фінансування університетів. Його суть полягає в тому, що кошти отримуються від фондів, корпоративних донорів або осіб, що діють незалежно від уряду і на благо суспільства шляхом підтримки діяльності університету за рахунок грантів або нефінансових засобів (пожертви землі, будівлі тощо) або оперуючи своїми власними програмами [3].

У діяльності ВНЗ також часто трапляється цільове фінансування, за якого кошти виділяються на досягнення конкретних цілей, поставлених органами держави чи місцевого самоврядування. В такому разі кошти розподіляються через конкурсний відбір або ж безпосередньо виділяються університету.

Таким чином, у світовій практицв налічується різноманіття моделей фінансування університетів. На основі проведеного аналізу загалом їх можна умовно розділити на два види залежно від джерела фінансування: публічне (державне та муніципальне) та приватне.

Моделі публічного фінансування характерні для університетів, що утримуються за рахунок коштів центральних, регіональних та місцевих органів влади. Моделі з приватним фінансуванням опираються на приватні джерела фінансових ресурсів, а саме: грошові кошти студентів (батьків, домогосподарств), неурядових організацій, благодійних фондів та підприємств. На практиці доволі важко зустріти чисту модель з державним чи приватним фінансуванням. Крім того, зустрічається безліч варіацій як в межах публічної, так і приватної моделей фінансування. Значимість кожної з них варіюється від однієї держави до іншої.

На сьогодні відомі країни, в котрих університети майже повністю фінансуються за рахунок державних коштів, зокрема державне фінансування вищої освіти становить 95\% і вище в скандинавських країнах (Данія, Фінляндія, Ісландія, Норвегія, Швеція), а також в Австрії, Бельгії, Чеській Республіці, Естонії, Франції та Німеччині [3]. В інших країнах, серед яких Угорщина, Ірландія, Італія, Нідерланди, Латвія, Польща, Словаччина та Іспанія, а також Великобританія, за рахунок публічних коштів університети покривають менше 90\% своїх видатків. Однак органи влади цих країн переважно можуть приймати рішення про запровадження, скасування або зміну рівня плати за навчання, тому для цих країн характерні як державні, так і приватні моделі фінансування.

Для країн, що не входять в СС, але є членами Організації економічного розвитку та співробітництва (ОЕСР), система фінансування вищої освіти характеризується більшою залежністю від приватного сектору. Наприклад, у США тільки половина від загального обсягу коштів на вищу освіту надходить із бюджетних фондів. Порівнюючи фінансування вищої освіти в чотирьох країнах, що не входять в СС, але $\epsilon$ членами ОЕСР (Австралія, Канада, Нова Зеландія і Сполучені Штати), стає очевидним, що ці країни здатні краще диверсифікувати джерела фінансування, розподіляючи фінансове навантаження між публічним i приватним сектором. Саме в цих країнах плата за навчання становить значну частку доходів ВН3, однак це не є перепоною для державної підтримки, що надається студентам у різних формах, у т. ч. стипендії, гранти та кредити для того, щоб компенсувати будь-які негативні наслідки платного навчання та забезпечити доступність освіти на всіх іiі рівнях. Більшість держав-членів ЄС дотримуються політики безкоштовної освіти на всіх рівнях (у т. ч. вищої освіти), тому це потенційне джерело доходу не може бути використане ними для збільшення доходів університетів [4].

3 кожним роком університети більшості країн постають перед зростаючою потребою в додаткових фінансових ресурсах, котрі вони не здатні отримати з приватних та публічних джерел. Створення додаткових доходів з інших джерел сприймається все більш необхідним для довгострокового фінансового забезпечення університетів. Тому все частіше у структурі доходів ВНЗ з'являються надходження від надання послуг (наприклад, здача в оренду об'єктів, послуг громадського харчування, консультації і т. д.), благодійних коштів, а також грантові кошти. В середньому ці типи додаткових джерел доходу перевищують $10 \%$ доходу університетів [5, с. 27].

Велику роль у фінансуванні вищої освіти відіграють регіональні органи влади, зокрема органи місцевого самоврядування, причому вона варіюється від країни до країни. У таких країнах, як Бельгія, Німеччина та Іспанія, регіональні органи влади здатні впливати на всі сфери фінансових відносин університетів. У Данії, Греції, Франції, Італії, Австрії, Швеції, Чехії та Польщі регіональні органи влади відіграють незначну роль у регулюванні фінансової діяльності ВНЗ. У більшій частині європейських країн регіональні органи влади не здатні впливати на зміну моделей фінансування університетів, змінювати вартість навчання (Ірландія, Нідерланди, Фінляндія, Великобританія, Естонія, Латвія, Литва, Угорщина, Мальта, Словацька Республіка.

Вищевикладене спростовує загальнопоширене твердження про те, що витрати на вищу освіту повинна нести особа, яка здобуває вищу освіту, або про те, що у розвинутих країнах фінансування вищої освіти здійснюється переважно за рахунок фінансових ресурсів домогосподарств. Проведений аналіз структу- 
ри витрат на освіту в окремих розвинутих країнах, освітні системи котрих мають хорошу репутацію, не підтверджує таку тезу, позаяк це не відповідає реальним фактам.

Одна з найбільш значущих відмінностей поточного стану системи освіти України полягає у значно нижчих, ніж у розвинутих країнах, абсолютних показниках фінансування. Якщо у відносному вимірі (частка витрат на освіту у ВВП) зведений освітній бюджет України є за світовими стандартами високим і становить 6-8\% ВВП, то абсолютні показники (засновані на обсягах ВВП України) є значно нижчими, ніж відповідні показники європейських країн зі співмірною кількістю населення. Наприклад, порівняно 3 Польщею - вони менші приблизно у два рази, Іспанією - у чотири рази. Водночас понад 90\% державних інвестицій у галузь освіти в Україні спрямовується на утримання - заробітну плату, сплату комунальних послуг, харчування та ін. [3], тобто переважна частина коштів, що витрачаються на систему освіти, йде на підтримання поточного стану, а не на розвиток.

Загалом недержавне фінансування освіти в Україні майже повністю зводиться до залучення коштів домогосподарств, які сплачують за навчання студентів, а частка витрат юридичних осіб $є$ мізерною i знаходиться на рівні 2\%. У західних державах ситуація інша, там юридичні особи фінансують у середньому 4-5\%, а в інших країнах (Австралія, Австрія, Канада, Нідерланди, Німеччина, США, Швеція) - навіть більше $10 \%$ витрат на вищу освіту. Така ситуація зумовлює необхідність ширшого залучення у фінансування вищої освіти України інших приватних агентів, зокрема підприємств та корпорацій, які потребують відповідних фахівців. Заохочувальним стимулом у такому разі можуть служити податкові пільги для підприємств, котрі готують фахівців для своїх потреб за власні кошти.

В Україні донедавна для фінансування університетів використовувалася модель, яка базується на потребах ВНЗ. Фінансування ВНЗ України за цією моделлю здійснювалося з бюджету на підставі витрат минулих років. Обсяги фінансування повністю залежали від кількості студентів, що призводило до погіршення якості вищої освіти, оскільки університети за цих умов не зацікавлені у відрахуванні неуспішних студентів [3].

Формалізований контроль за виконанням державного замовлення ніяк не стимулював ВНЗ йти назустріч потребам суспільства, регіональним чи державним пріоритетам економіки. Фактично українські ВНЗ перебували у постійній боротьбі за фінансові ресурси, щоб покрити свої поточні потреби. Покриття тільки поточних потреб університетів не дає можливостей для якісного надання освітніх послуг. Лише 3,5\% коштів у вітчизняних навчальних закладах спрямовується на матеріально-технічне переоснащення, ремонт приміщень, закупівлю транспортних засобів, техніки.

Кардинальні зміни в механізмі державного фінансування українських університетів були започатковані в кінці 2019 р., коли Міністерство освіти і науки України суттєво змінило підхід до фінансування ВНЗ. 24 грудня 2019 р. міністеркою освіти і науки Г. Новосад було презентовано Концепцію реформування фінансування та управління закладами вищої освіти [6]. Відповідно до неї, з 2020 р. 3ВО фінансуються за формулою, де університети з кращими результатами діяльності отримують більше фінансування порівняно iз бюджетом минулого року. Відтак, вже з січня 2020 р. працює формульний підхід - 80\% бюджету ВН3 отримуватимуть гарантовано для базових видатків, решту - залежно від позиції в міжнародних рейтингах, відсотка працевлаштування випускників, обсягу залучених з альтернативних джерел коштів тощо [7].

Таким чином, Міністерство освіти і науки починає фінансувати університети не просто за кількість студентів, які в них навчаються, а за результати роботи, які вони мають. Університети, які займаються науковою діяльністю, отримують замовлення на дослідження і мають міжнародні гранти, - це неодмінна ознака сильних шкіл та науковців-викладачів і варто використовувати ці показники, як один із критеріїв для державного фінансування.

До 2020 р. фінансування університетів майже на 100\% залежало від кількості студентів. Зараз вага цього показника знижується і через три роки становитиме менш ніж 50\% [8]. Саме тому розрахунок обсягу фінансування у 2020 р. розробляло МОН за конкретними показниками, серед яких: масштаб університету; контингент; регіональний коефіцієнт; позиції у міжнародних рейтингах; обсяг коштів на дослідження, які університет залучає від бізнесу чи з міжнародних грантів. 32021 р. до цих показників додасться працевлаштування випускників, які МОН буде відстежувати через онлайн-систему.

Для поступовості переходу у 2020 р. були запроваджені обмеження для мінімальної та максимальної зміни бюджету кожного ЗВО - 95\% та 120\% від 2019 р. відповідно. Міністерство освіти і науки опублікувало детальний розподіл коштів з державного бюджету між закладами вищої освіти. Всього на університети у 2020 р. МОН витратить 16,26 млрд грн. Фінансування за формулою отримають 136 закладів вищої освіти та 12 їхніх філій, які мають власні кошториси. У 2020 р. 94 заклади отримають 100-120\% від бюджету 2019 р., а 54 - 95-99\% від бюджету 2019 р. [8]. 
МанюкГ.

Адміністративно-правові проблеми фінансування університетів

В результаті розрахунку фінансування за формулою у 2020 р. 17 університетів отримають збільшення фінансування на понад 15 млн грн. 3-поміж них - Київський політехнічний інститут ім. І. Сікорського, Львівська політехніка, Харківський політехнічний інститут, Сумський державний університет, Ужгородський національний університет тощо [7]. Ті університети, що отримають менший обсяг фінансування, мають час та можливість покращити свої показники або не покращити і швидко перестати отримувати державне фінансування.

Приватні ВНЗ також зможуть отримати доступ до бюджетного фінансування за дотримання вимог з індикативної собівартості (мінімальної ціни контрактного навчання).

Нова система фінансування вищої освіти стимулює університети розвиватись та відповідати на запити ринку праці. Отримавши збільшене фінансування вже цього року, вони можуть вкласти ці гроші в підвищення якості. Наприклад, збільшити заробітну плату сильним викладачам. Це підвищить їхню мотивацію та покращить якість освіти у ВНЗ [9].

Показники, за якими МОН робить розрахунок розподілу фінансування, дають університетам чітке розуміння, за якою траєкторією їм потрібно рухатись, щоб покращувати свої позиції. Відтепер фактична кількість студентів за бюджетною формою навчання (контингент) - лише один із семи показників, які впливають на формування бюджету. Протягом наступних трьох років важливість цього показника буде зменшуватись.

Додатково держава стимулює університети зберігати свій профіль, технічні університети - підтримувати саме технічні спеціальності. Держава за одного студента на технічній спеціальності буде давати на $60 \%$ більше фінансування, ніж за студента економічних спеціальностей, гуманітарних. Таким чином держава стимулює технічні університети не втрачати свій профіль, вкладатися в технічні, інженерні спеціальності, яких не вистачає [8].

Показник масштабу стимулює заклади вищої освіти об'єднуватись та ефективно використовувати ресурси. Так, університети, у яких навчається менше 1000 студентів, будуть отримувати менше, а ті, де три, п’ять і десять тисяч студентів, - навпаки отримуватимуть більше [9].

Особливістю нового порядку фінансування ЗВО є також застосування регіонального коефіцієнта, завдяки чому держава підтримує регіональні університети. Застосування регіонального коефіцієнта у формулі дало змогу регіональним університетам у 2020 р. отримати краще фінансування. У попередні роки через відплив абітурієнтів у великі міста регіональні ЗВО втрачали студентів та не мали ресурсів для розвитку [10].

Ще одним показником, який враховується для визначення розміру державного фінансування університетів, є представництво вітчизняних університетів у міжнародних рейтингах. Міністерство, зокрема, враховує позиції університетів у таких рейтингових системах, як QS World University Rankings, The Times Higher Education World University Rankings та Academic Ranking of World Universities. Наразі п’ять українських 3ВО, які входять до цих рейтингів, отримали додаткове фінансування за цим показником [7].

Показником, який стимулює університети розвивати науку та диверсифікувати джерела надходження грошей, а відтак враховується в процесі його державного фінансування, є розмір коштів на дослідження, які університет залучає від бізнесу та з міжнародних грантів, свідчить, що закладу довіряють донори та / або бізнес.

32021 р. МОН почне застосовувати для розрахунку фінансування ЗВО такий показник, як працевлаштування випускників. Відтак університет отримуватиме більше фінансування, якщо його випускники будуть працевлаштовуватися на посадах, які вимагають кваліфікації вищої освіти [9].

У 2020 р. МОН запустить електронну систему, яка буде моніторити, чи працюють випускники того чи іншого університету на посаді, що вимагає вищої освіти. Цей показник буде стимулювати університети підвищувати якість освіти, враховувати потреби ринку праці та сприяти працевлаштуванню своїх студентів [7].

Висновки. Загалом варто зазначити, що пошуки та розробка ефективної моделі фінансування університетів повинні враховувати всі види діяльності університету та грунтуватися на засадах ефективності, прозорості та автономії і служити основній меті - надання якісних освітніх послуг, підготовка затребуваних фахівців на ринку праці, а також проведення результативних наукових досліджень. Уже давно варто було змінити об’єкт фінансування, тобто відійти від фінансування потреб університету до фінансування конкретних завдань, цілей і отримання заздалегідь визначених результатів. Міністерство освіти та науки зробило важливий крок до прозорості та відкритості фінансування університетів, запровадивши нову систему розподілу коштів. Вперше Міністерство освіти і науки оприлюднило засади та критерії розподілу 
державних коштів між закладами вищої освіти. Кожен університет отримав фінансування залежно від результатів своєї роботи та величезний стимул розвиватись більш динамічно. В підсумку це прведе до підвищення відповідальності всіх учасників освітнього процесу і дасть можливість ефективно використати обмежені фінансові ресурси.

\section{Список використаних джерел}

1. Friedel J., Thornton Z., D’Amico M., Katsinas St. «Performance-Based Funding: The National Landscape», Education Policy Center. September 2013. URL : http://uaedpolicy.ua.edu/uploads/2/1/3/2/21326282/pbf_917_web.pdf (дата звернення: 14.09.2019).

2. DEFINE Thematic Report: Performance-Based Funding of Universities in Europe by AnnaLena Claeys-Kulik and Thomas Estermann: European University Association. 2015. 61 p.

3. Education at a Glance 2014: OECD Indicators, OECD Publishing. URL : http://www.oecd-ilibrary.org/ education/education-at-a-glance-2014_eag-2014-en;jsessionid=1vq3qgkpmv9h.x-oecd-live-03 (дата звернення: 17.09.2019).

4. Мирошникова О. Х. Постсовременный университет: взгляд в будущее. Мир науки. 2015. № 3. URL : http://mir-nauki.com/ PDF/02PDMN315.pdf.

5. Designing strategies for efficient funding of higher education in Europe by Thomas Estermann, Enora Bennetot Pruvot and Anna-Lena Claeys-Kulik : EUA. 2013. 20 p.

6. Концепція реформування публічного фінансування та управління закладами вищої оcвіти. URL : https:// drive.google.com/file/d/1obC0K1NM hh9soat7LK9y-ughV4n070-h/view (дата звернення: 12.09.2019).

7. Губар О. Український уряд змінив підхід щодо фінансування вишів. DW. 24.12.2019. URL : https://p. dw.com/p/3VIWX (дата звернення: 18.09.2019).

8. МОН представило нову систему фінансування вузів. LB.ua. URL : https://ukr.lb.ua/ society/2020/01/24/448064_mon_predstavilo_novu_sistemu.html (дата звернення: 14.09.2019).

9. Більше грошей - сильнішим. МОН опублікувало розподіл держфінансування університетів у 2020 році. 24.01.2020. URL : https:/mon.gov.ua/ua/news/bilshe-groshej-silnishim-mon-opublikuvalorozpodil-derzhfinansuvannya-universitetiv-u-2020-roci. (дата звернення: 9.09.2019).

10. Державне фінансування університетів тепер не залежатиме від кількості бюджетників: що зміниться. Рубрика. 02.02. 2020. URL : https://rubryka.com/2020/02/02/derzhavne-finansuvannya-universytetiv-teperne-zalezhytyme-vid-kilkosti-byudzhetnykiv-shho-zminytsya/ (дата звернення: 14.08.2019).

\section{References}

1. Friedel J., Thornton Z., D’Amico M., Katsinas St. (2013). Performance-Based Funding: The National Landscape. Education Policy Center. Retrieved from http://uaedpolicy.ua.edu/uploads/2/1/3/2/21326282/ pbf_9-17_web.pdf (in English).

2. DEFINE Thematic Report: Performance-Based Funding of Universities in Europe (2015). By AnnaLena Claeys-Kulik and Thomas Estermann: European University Association (in English).

3. Education at a Glance 2014: OECD Indicators, OECD. Retrieved from http://www.oecd-ilibrary.org/ education/education-at-a-glance-2014_eag-2014-en;jsessionid=1vq3qgkpmv9h.x-oecd-live-03 (in English).

4. Miroshnikova, O.H. (2015). Postsovremennyiy universitet: vzglyad v buduschee. [Post-modern university: a look into the future]. Mir nauki. Nauchnyiy internet-zhurnal - The World of Science. Scientific Internet Magazine, 3. Retrieved from http://mir-nauki.com/ PDF/02PDMN315.pdf (in Russian).

5. Designing strategies for efficient funding of higher education in Europe (2013). By Thomas Estermann, Enora Bennetot Pruvot and Anna-Lena Claeys-Kulik: EUA (in English).

6. Kontseptsiia reformuvannia publichnogo finansuvannya ta upravlinnya zakladamy vishchoi osvity [The concept of reforming public funding and management of higher education institutions]. Retrieved from https:// drive.google.com/file/d/1obC0K1NM hh9soat7LK9y-ughV4n070-h/view (in Ukrainian).

7. Gubar, O. (2019). Ukrayinskiy uryad zminyv pidhid shchodo finansuvannya vyshiv [The Ukrainian government has changed its approach to financing higher education institutions]. DW. 24.12.2019. Retrieved from https://p.dw.com/p/3VIWX (in English).

8. MON predstavylo novu systemu finansuvannya vuziv [MON introduced a new system of financing universities]. Retrieved from https://ukr.lb.ua/society/2020/01/24/448064_mon_predstavilo_novu_sistemu.html (in Ukrainian). 
Манюк Г.

Адміністративно-правові проблеми фінансування університетів

9. Bilshe groshei - sylnishym. MON opublikuvalo rozpodil derzhfinansuvannya universitetiv u 2020 rotsi [More money is stronger. The Ministry of Education and Science published a breakdown of state funding for universities in 2020]. 24.01.2020. Retrieved from https://mon.gov.ua/ua/news/bilshe-groshej-silnishim-monopublikuvalo-rozpodil-derzhfinansuvannya-universitetiv-u-2020-roci (in Ukrainian).

10. Derzhavne finansuvannia universytetiv teper ne zalezhatyme vid kilkosti biudzhetnykiv: shcho zminytsia. Rubryka [State funding for universities will no longer depend on the number of state employees: what will change. Heading] (2020). URL: https://rubryka.com/2020/02/02/derzhavne-finansuvannya-universytetivteper-ne-zalezhytyme-vid-kilkosti-byudzhetnykiv-shho-zminytsya/ (in English).

Стаття надійшла до редакції 02.12.2019. 